\title{
Guest Editors' Introduction: Sociology in Belgium, National Divisions, International Ambitions
}

\author{
Kaat Louckx ${ }^{1} \cdot$ Raf Vanderstraeten ${ }^{2}$
}

Published online: 3 June 2020

(C) The Author(s) 2020

Belgium is a relatively small country with today about 11.5 million inhabitants. Like some other small countries in Europe, which border on much larger neighbors, it has tried to acquire and maintain a visible international role. Since the latter part of the twentieth century, for example, the headquarters of the European Union (EU) and NATO are located in Brussels, which is both the bilingual capital of Belgium and the capital of Europe.

Belgium already enjoyed an international reputation shortly after its creation in 1830 , in part because of its politically 'calm' climate (especially in comparison with its tumultuous neighbors Germany and France) and its strong liberal orientation, as expressed by its constitutionally entrenched freedoms of religion, education and the press. In this context, the Belgian universities also acquired an international appeal that would determine the course of its scientific undertakings. Both the internal characteristics and the external (international) ambitions of this 'small border country' would have a strong impact on the development of the social sciences and sociology in Belgium (Vanderstraeten and Louckx 2018).

Exemplary of the international ambitions of the new Belgian state in the burgeoning field of the social sciences is the work of the Belgian homo statisticus Adolphe Quetelet, who, in the mid-nineteenth century, not only devoted much of his energy to the elaboration of a "physique sociale" (social physics). In addition to establishing national institutions for the collection of social data, he also embodied a remarkably international approach to science, in which the collection of internationally comparable data was paramount. Quetelet played an active role in the development of international scientific institutions and publication formats, a role that has remained largely underexplored by historians and sociologists to this day. At the same time, Quetelet's work shows how the collection of social data was intrinsically bound up with the establishment of a bureaucratic apparatus that had an interest in the production of administrative statistics.

At the very end of the nineteenth century, the first wave of disciplinary institutionalization of sociology in Belgium was mainly driven by developments in the European superpowers

Kaat Louckx

klouckx@uni-bonn.de

1 University of Bonn, Bonn, Germany

2 University of Ghent, Ghent, Belgium 
France, Germany and England. Despite the existing political-religious divisions (or the Catholic, socialist and liberal "pillars"), which echoed broader ideological conflicts in Europe as a whole, the country had high international ambitions and attempted to promote scientific internationalism. On the liberal and socialist side, the successful entrepreneur and philanthropist Ernest Solvay founded several internationally-oriented research institutes in Brussels, including an Institut des Sciences Sociales and its successor, the highly eclectic Institut de Sociologie Solvay. In the same period of time, an explicitly Catholic sociology would also take shape in Belgium.

Some of Belgium's territorial and colonial ambitions, which were driven by its internationalism, also provided an early impulse for sociological research. In 1885, the Congo Free State in Central Africa had become a personal colony of King Leopold II of Belgium. However, the system of economic exploitation led to international diplomatic pressure on the Belgian state to take official control of the country, which eventually happened in 1908, thus creating Belgian Congo. In many Belgian networks it was argued at the time that "civilization projects" could be launched in Congo, provided that sufficient scientific knowledge was gathered about the local settings in which the "primitive" populations of Congo were living. Until 1960, when the Congo became independent from Belgium, a "descriptive sociology" of these populations would primarily serve to underpin the "right to colonize."

After WWI, "brave poor little Belgium" struggled to regain its international role. During the Great War, which took place on Belgian territory from 1914 until the end of 1918, all academic institutions in Belgium were closed. Because the post-war reconstruction of the country absorbed most of the resources and attention, and because the isolation of international scientific developments during the war years could not easily be overcome, Belgium had difficulty regaining a prominent position in the expanding international research fields, including the social sciences. Within Belgium, the growing linguistic tensions between the French-speaking (or Walloon) and Dutch-speaking (or Flemish) communities moreover led to the increasing "regionalization" of scientific research. These communities were not only hardly able to establish strong links with international scientific currents, but also started to evolve in relative isolation from each other.

After WWII, the expansion of the university system would allow for a gradual revival of the social sciences in Belgium. In this period of time, the power of the "pillars" would gradually decline, while the linguistic divisions would become particularly prominent. Since the early 1960s, Belgium has gradually been transformed into a federal state, whose regions and jurisdictions are defined by linguistic borders. Flanders (in the north of the country, with currently about $58 \%$ of the population) and Wallonia (in the south, $\pm 32 \%$ ) are now understood as unilingual regions, while Brussels (in the center of the country, $\pm 9.5 \%$ ) has been defined as a bilingual region. Besides, there is a small German-speaking community in the east of the country $( \pm 0.6 \%)$.

The political reorganization of the country is both reflected in and reinforced by the way in which the collection of social data is now organized. Most 'facts' are now gathered at the regional level; statistical data at the national or federal level have become scarce. Whether (and in which respects) Belgium remains a relevant observation unit can nowadays hardly be discussed, because relevant or comparable data are lacking. Not the available data, but the lack thereof thus shows that the two regions have become different worlds. These 'naturalized' divisions also determine the context in which sociology in Belgium is currently developing. While the political and religious 
differences in the country have often been thematized in twentieth century sociological research, this was not the case for the linguistic and regional tensions.

In the past decades, the academic landscape in Belgium has become highly fragmented, as Belgium itself. A national community of Belgian sociologists has not developed. We can therefore speak of sociology in Belgium, but not of Belgian sociology. Most sociologists are now located either in the Flemish or in the French-speaking part of Belgium, but scientific cooperation between the different language communities remains very limited. While the sociologists in the French-speaking part of the country often orient themselves towards France, different strategies have been followed in Flanders. Not only did Flemish sociologists try to establish closer ties with the sociological community in the Netherlands, but a stronger orientation towards the Anglo-Saxon world has also emerged. In many regards, this division is similar to the gulf between the French-speaking and the English-speaking research communities in Canada, "north of the border" of the US, to which The American Sociologist devoted ample attention in its Spring issue of 2002.

Since the last decades of the twentieth century, seven (out of a total of twelve) Belgian universities offer Bachelor's and/or Master's degrees in sociology. Some English-language BA and MA programs have recently also been launched, either for Social Sciences (broadly defined) or Sociology. Next to these programs, several related MA programs have been established, such as "Social Work and Social Policy," "Gender and Diversity," "Social and Cultural Anthropology," "Journalism," "Conflict and Development," etc. Linked with the rise of these MA programs, the BA programs in Sociology have felt the pressure to broaden their scope and prepare for these different options. It goes without saying, however, that this broader orientation threatens to go at the expense of the acquisition of subject-specific competences.

Since the beginning of the twenty-first century, with the introduction of a 'performancebased' funding system for academic research which is highly dependent on the number of publications in journals indexed by Web of Science, explicit internationalization requirements have been imposed on all research fields in Flanders. Investments in the 'knowledge economy' have also created new opportunities for researchers, especially in Flanders, which is currently the more prosperous part of Belgium. But while the number of (post-)doctoral researchers grew here very strongly between 1982 and 2016 (+900\%), the number of professorships remained relatively stable until 2010, after which it started to increase $(+30 \%)$. It should be added that professorial appointments are highly determined by nationality (in favor of compatriots) and career path (in favor of internal candidates). Unlike in the US (see DiFuccia et al. 2007; Turner 2016: 66-80; Bucior and Sica 2019), men also continue to occupy most tenured positions, especially at the top of the career ladder. While, in Belgium, positions in academia are not allocated on the basis of gender quota, it is difficult to foretell when this situation will change.

The situation is not very different in the field of sociology. Despite the expansion of the number of available professorships, many young sociologists face a situation of "publish and perish." For many sociologists with independent research experience, routes into nonacademic jobs or positions still need to be secured. On the other hand, the increasing orientation towards Anglo-Saxon publication outlets, and thus towards the academic 'outside world,' may be able to enhance (again) the visibility of some Belgian scholars.

The broad, universal orientation that characterized sociology in the past has now made way for the emergence of specialized subdomains, such as cultural sociology, demography, social policy, (political) opinion research, sociology of labor, sociology of health, 
environmental sociology, etc. In Belgium, as in other countries, the urge to secure extra funding has led to a dominance of policy-oriented sociological research, with a strong normative orientation and "social problems stance." Specific political and normative agendas thus play an important role in the sociology departments in Belgium. Many members of these departments identify themselves as social reformers and focus on themes that are of interest to the offices which sponsor their research, such as ethnic minorities, social inequality and welfare distribution, poverty and social exclusion, sustainable development, etc. Clearly, the aforementioned tendencies do not encourage an experimental attitude needed for the development of more 'risky,' independent types of research. Nor are they conducive to the development of generalizable sociological knowledge or less policyoriented forms of sociology, such as social theory and historical sociology.

In the past, the complexity of Belgium proved attractive to some American sociologists, such as Renée Fox, who concluded on the basis of almost two decades of research in Belgium: "the smaller the country, the more complex its social system!" (Fox 1978: 207). According to Fox, the complexities of Belgium allowed for a fascinating comparative case study, which could also serve to identify distinctive American characteristics. We believe that a careful sociological reflection on developments in Belgium might still be relevant. In particular, we believe that little Belgium, with its internal differences and divisions, and the resulting creative, sometimes incongruous solutions to conflicts, can be an interesting source to clarify, but also to question, the relationship between sociology and the nation-state. The following papers give an overview of the history and current situation of sociology in brave little Belgium, produced by academics from both sides of the language border. We hope that you enjoy reading these papers.

Funding Information Open Access funding provided by Projekt DEAL.

Open Access This article is licensed under a Creative Commons Attribution 4.0 International License, which permits use, sharing, adaptation, distribution and reproduction in any medium or format, as long as you give appropriate credit to the original author(s) and the source, provide a link to the Creative Commons licence, and indicate if changes were made. The images or other third party material in this article are included in the article's Creative Commons licence, unless indicated otherwise in a credit line to the material. If material is not included in the article's Creative Commons licence and your intended use is not permitted by statutory regulation or exceeds the permitted use, you will need to obtain permission directly from the copyright holder. To view a copy of this licence, visit http://creativecommons.org/licenses/by/4.0/.

\section{References}

Bucior, C., \& Sica, A. (2019). Sociology as a female preserve: Feminization and redirection in sociological education and research. The American Sociologist, 50(1), 3-37.

DiFuccia, M., Pelton, J., \& Sica, A. (2007). If and when sociology becomes a female preserve. The American Sociologist, 38(1), 3-22.

Fox, R. C. (1978). Why Belgium? Archives européennes de Sociologie / European Journal of Sociology, 19(2), 205-228.

Turner, S. (2016). American sociology: From pre-disciplinary to post-normal. London: Palgrave Macmillan.

Vanderstraeten, R., \& Louckx, K. (2018). Sociology in Belgium: A sociological history. London: Palgrave Macmillan.

Publisher's Note Springer Nature remains neutral with regard to jurisdictional claims in published maps and institutional affiliations. 